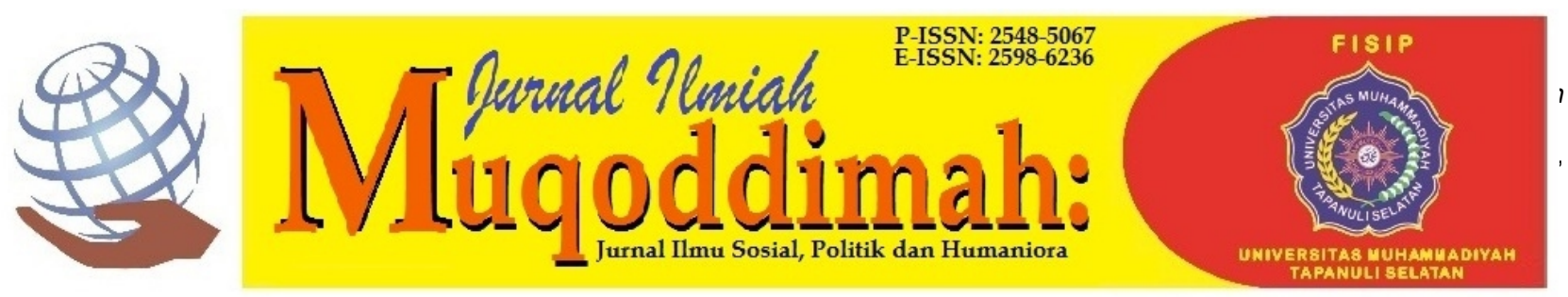

\title{
Pengaruh Australia Terhadap Kebijakan Domestik Indonesia Dalam Menanggulangi Aksi Terorisme Bom Bali Satu
}

\author{
Yeni Oktarina ${ }^{1)}$, Regina Putri Mulyawati2), Sheila Hannah Damayanti ${ }^{3)}$, Nabila Farah Khanuris ${ }^{4}$ \\ Fakultas IImu Sosial dan IImu Politik, Universitas Muhammadiyah Malang \\ JI. Raya Tlogomas, Malang - Jawa Timur \\ yeniktrn28@gmail.com \\ rp4804008@gmail.com
}

\begin{abstract}
Abstrak
Kasus terorisme bom Bali satu merupakan suatu isu global yang dipengaruhi oleh adanya gerakan transnasional dalam organisasi islam radikal. Pada penelitian ini akan mengkaji tentang proses perubahan kebijakan terorisme dalam pemerintah di Indonesia dengan harapan untuk dapat mengatasi konflik terorisme bom Bali satu. Pendekatan yang digunakan merupakan studi intermestik melalui transnasional dengan model networks dalam mengkaji adanya perubahan kebijakan publik terhadap terorisme yang ditinjau melalui pendekatan tersebut. Metode yang digunakan terhadap penelitian ini yaitu kualitatif yang bersifat deskriptif. Dalam pembahasan juga membahas adanya pengaruh dari peran Australia hingga terbentuknya kebijakan terhadap kontra terorisme di Indonesia seperti yang kita ketahui dalam kebijakan yang telah dibentuk oleh pemerintah masih kurang tepat sejak masa orde lama hingga pada orde baru. Dalam hal ini kemudian adanya perubahan kebijakan tersebut dimulai pada masa reformasi ini. Setelah adanya konflik terorisme bom Bali satu tersebut akhirnya dapat merubah kebijakan public mengenai terorisme. Implikasi dari adanya suatu jaringan yang Indonesia bentuk sehingga dalam hal ini kemudian dapat terciptanya suatu kerja sama dalam penyelesaian terhadap kasus terorisme serupa.
\end{abstract}

Kata kunci: Bom Bali, Kebijakan, Terorisme.

\begin{abstract}
The Bali bombing terrorism case is a global issue that is influenced by the transnational movement in radical Islamic organizations. In this study, it will examine the process of terrorism policy change in the government in Indonesia in the hope of being able to resolve the Bali bombing terrorism conflict. The approach used is an international study through transnational with networks models in examining changes in public policies against terrorism which are reviewed through this approach. The method used in this research is descriptive qualitative. In the discussion also discussed the influence of the role of Australia to the formation of policies against counter terrorism in Indonesia as we know in the policies that have been formed by the government are still not quite right from the old order to the new order. In this case, the change in policy began during this reform period. After the Bali bombing terrorism conflict, one can finally change public policies regarding terrorism. The implication of the existence of a network that Indonesia forms so that in this case can then create a cooperation in the resolution of similar terrorism cases.
\end{abstract}

Keywords: Bali Bombing, Terrorism, Policy. 
JURNAL ILMIAH MUQODDIMAH: Jurnal IImu Sosial, Politik Dan Humaniora E-ISSN : 2598-6236

http://jurnal.um-tapsel.ac.id/index.php/muqoddimah
Pengaruh Australia Terhadap Kebijakan Domestik Indonesia Dalam Menanggulangi Aksi Terorisme Bom Bali Satu

(Yeni Oktarina, Regina Putri Mulyawati, Sheila Hannah Damayanti, Nabila Farah Khanuris)

\section{PENDAHULUAN}

Terorisme bukanlah sebuah hal yang baru bagi dunia dan Indonesia. Namun, kembali menjadi perbincangan hangat setelah adanya kejadian pengeboman di gedung kembar World Trade Center (WTC) di New York dan sebagian gedung Pentagon DC pada tanggal 11 September 2001. Sehingga, fokus politik Amerika Serikat berubah dan memprioritaskan perang melawan terroris menjadi yang utama.(Jemadu, 2008) Indonesia sendiri juga memiliki sejarah yang panjang mengenai isu terrorisme ini. Dibuktikan sejak tahun 1940-an, dimana adanya teror politik yang diarahkan untuk menghadapi penjajahan dari Belanda.(Mukhtar, 2016) Dalam merespon aksi terorisme ini, sebagian negara merespn dengan berbagai sikap, ada yang tidak menerima toleransi apapun terhadap aksi terrorisme ini, dan ada juga sebagian negara yang masih berikap biasa saja. Hal ini dikarenakan pada saat itu aksi terrorisme ini belum menjadi fokus utama, dan masih banyaknya negara yang menganggap enteng permasalahan terrorisme ini. Hingga adanya aksi terrorisme di WTC yang kemudian dilanjutkan dengan pengeboman Bali tahun 2002, yang akhirnya membuat semua negara semakin waspada.(Pratiwi, 2016)

Setelah terjadinya peristiwa pengeboman di gedung WTC tersebut, fokus utama dalam setiap pertemuan internasional dan global menjadikan terrorisme sebagai isu utama yang harus dibahas. Terjadinya suatu aksi terrorisme bukanlah hal yang mudah untuk ditebak. Di Indonesia sendiri tepat pada tanggal 12 Oktober 2002, terjadi aksi terrorisme di Bali yang memakan korban jiwa masyarakat sipil dan Warga Negara Asing (WNA), yang mana WNA dari Australia yang paling banyak menjadi korban. Total dari keseluruhan korban dalam Bom Bali ini mencapai 180 orang dan melukai ratusan orang lainnya(Pratiwi, 2016). Getaran yang dirasakan dari Bom bali ini dapat dirasakan hingga jarak 12 kilometerdenag bunyi yang terdengar sampai puluhan kilometer, serta asap setinggi 100 meter (Prastiwi, 2018)

Melihat dari hubungan Indonesia dan Australia yang cenderung rumit dalam beberapa bidang, tidak menjadikan hubungan diantara kedua negara ini kandas begitu saja. Kedua negara ini saling membutuhkan. Hal ini dikarenakan posisi kedua negara yang berdekatan, dn juga Indonesia yang merupakam sebuah negara dengan populasi Muslim terbanyak mnjadikan Australia tidak segan untuk membantu Indonesia (Indonesia, 2017)

Dengan semakin maraknya aksi terrorisme ini, Indonesia membuat banyak kebijakan yang dimaksud agar dapat menanggulangi aksi kejahatan tersebut. Sebagai contoh, kita dapat melihat kebijakan domestik Indonesia pada masa orde lama dan masa reformasi. Dimana, pada masa Orde Baru, penanggulangan terhadap aksi terrorisme dilakukan dengan menggunakan pendekatan yang mengutamakan adanya peran TNI sebagai sebuah alat negara. Sedangkan pada masa reformasi, penanggulangan terhadap aksi terorisme dilakukan dengan cara membuat sebuah kebijakan yang menekankan pada penegakan hukum, dimana aksi terrorisme dikaitkan dengan tindakan pelanggaran hukum pidana, walaupun sebenarnya aksi terrorisme ini dikategorikan kedalam kejahatan yang luar biasa (extraordinary crime).(Mukhtar, 2016)

Indonesia sudah membentuk Undang-undang mengenai aksi terirorisme ini, yaitu; adanya pasal 12 Undang-Undang Nomor 15 Tahun 2003 mengenai pemberantasan tindak pidana terrorisme, hal tersebut adalah sebuah kebijakan dan langkah strategis agar dapat memperkuat ketertiban dan keselamatan masyarakat yang dilakukan dengan tetap menjunjung tinggi hukum dan hak asasi manusia, tidak bersikap diskriminatif kepada suku, agama, ras, ataupun antargolongan. Selanjutnya, terddapat pasal 13 Undang-Undang Nomor 15 Tahun 2003 yang menyatakan bahwa setiap orang yang dengan sengaja memperlakukan atau memberi bantuan kepada pelaku tindak pidana terrorisme akan dikenakan hukuman pidana, dengan masa tahanan paling cepat tiga tahun dan paling lambat 15 tahun.(Mukhtar, 2016)

Selain itu, Indonesia juga membuat sebuah kebijakan mengenai kontra-terrorisme, yang mana kebijakan tersebut merupakan hasil yang didapatkan atas kerjasama dengan Australia. Indonesia bekerjasama dengan Australia dikarenakan pada saat terjadinya pengeboman Bali pertama, WNA Australia merupakan korban yang paling banyak, sehingga Australia langsung 
JURNAL ILMIAH MUQODDIMAH: Jurnal IImu Sosial, Politik Dan Humaniora E-ISSN : 2598-6236

http://jurnal.um-tapsel.ac.id/index.php/muqoddimah
Pengaruh Australia Terhadap Kebijakan Domestik Indonesia Dalam Menanggulangi Aksi Terorisme Bom Bali Satu

(Yeni Oktarina, Regina Putri Mulyawati, Sheila Hannah Damayanti, Nabila Farah Khanuris)

memberikan bantuan kepada Indonesia. Dengan adanya kerjasama yang menghasilkan kebijakan kontra-terrorisme ini, menjadikan hubungan kedua negara semakin membaik, serta merupakan salah satu jalan atau usaha menanggulangi aksi terrorisme yang dapat memperbaiki citra Indonesia di ranah Internasional.

Selain dengan Australia, Indonesia juga menjalin kerjasama dengan beberapa negara contohnya adapun seperti Amerika Serikat. Kerjasama dengan Amerika Serikat ini terikat dalam sebuah memorandum of understanding (MoU) (Wijayaka, 2018), yang mana dengan adanya kerjasama tersebut dapat memperkuat hubungan kedua negara dalam mengatasi aksi terorisme ini. Namun, disini penulis tidak memfokuskan pada pengaruh kebijakan domestic Indonesia dalam adanya kerjasama dengan Amerika. Tetapi, lebih memfokuskan, bagaimana kebijakan domestic Indonesia yang berkaitan dengan Ausralia. Seperti yang sudah dijelaskan diatas, dalam kasus pengeboman Bali 2002, WNA dari Australia merupakan korban terbanyak sehingga membuat Indonesia dan Australia tidak ragu untuk menjalin kerjasama sehingga menghasilkan sebuah kebijakan public untuk memerangi terorisme.

Kerjasama Indonesia dengan Australia menghasilkan terbentuknya Densus 88, yang kemudian dapat menangkap semua para sindikat terorisme yang terlibat dalam pengeboman Bali pertama ini. Namun, pendekatan hard power tersebut yang menggunakan Densus 88 , Brimob, dan anggota lainnya dapat memicu munculnya aksi-aksi balasan oleh para terrorisme. Hal ini dibuktikan dengan adanya aksi terrorisme baru yang terjadi setelah pengeboman Bali pertama tersebut. Selain itu, terdapat juga kecemburuan diantara para pasukan TNI seperti kopasus, denjaka, dan lainnya jika Indonesia tetap melakukan penanggulangan terrorisme ini dengan menggunakan Densus 88.(Mukhtar, 2016). Penglibatan anggota TNI ini tertulis dalam pasal 43 Ayat 1 yang enyebutkan bahwa tugas dari TNI dalam mengatasi terorisme adalah bagian dari operasi militer selain perang (Adyatama, 2020). Namun, terdapat penolakan akan ikut serta TNI dalam menanggulangi terorisme ini karena dapat mengancam Hak Asasi Manusia (HAM) dan $\mathrm{NI}$ tidak tunduk pada peradilan umum walaupun mereka bergerak dalam ranah penegakan hukum terorisme (CNN Indonesia, 2020)

Dengan adanya polemic diatas, Pemerintahan Indonesia cepat dalam menanggapinya. Pemerintah kemudian mengubah strategi dan aksi pemberantasan yang sebelumnya pendekatan bersifat hard power menjadi pendekatan soft power, yang dilakukan dengan cara deradikalisasi terhadap para pelaku terrorisme beserta keluarganya. Hal seperti ini yang menjadi sebuah pendekatan kemanusiaan yang berakar dari budaya Indonesia yang saling menghargai dan menghormati antar sesama.(Mukhtar, 2016)

Penelitian ini tidak dapat dilepaskan dari penelitian-penelitian yang sudah ada sebelumnya, seperti penelitian dari Hery Firmansyah yang berjudul Upaya Penanggulangan Tindak Pidana Terorisme di Indonesia.("UPAYA PENANGGULANGAN TINDAK PIDANA TERORISME di Indonesia," 2011). Menurut penelitian ini, maraknya aksi terorisme yang terjadi di berbagai belahan dunia acap kali menggemparkan berbagai belah pihak. Dan seperti yang kita ketahui, terorisme ini acap kali dikaitkan dengan seruan "Muslim" atau "Orang-orang Islam". Disini penulis sepakat tentang cara pencegahan atau upaya penanggulangan terorisme yang menggunakan upaya preventif, preemtif, dan represif sebagai upayanya menghalau terorisme. Juga, bagaimanapun bentuk pemerintah dalam menanggulangi permasalahan ini, agaknya jangan sampai menyenggol sikap diskriminasi terhadap sejumlah kalangan atau kelompok apalagi agama. Siapapun pelaku terorisme yang terjadi di berbagai tempat, harus dihukum sesuai dengan undang-undang yang berlaku tanpa melihat agama atau etnis pelaku.

Penelitian kedua merupakan jurnal dari Shara Yosevina Simanjuntak yang berjudul Analisis Kerjasama Bilateral Indonesia dan Australia dalam Penanggulangan Terorisme Sebagai Kejahatan Transnasional Terorganisir (2002-2015)(“13. ANALISIS KERJA SAMA BILATERAL INDONESIA DENGAN AUSTRALIA DALAM PENANGGULANGAN TERORISME SEBAGAI KEJAHATAN TRANSNASIONAL TERORGANISIR (2002-2015)," 2016) Aksi terorisme sebagai 
JURNAL ILMIAH MUQODDIMAH: Jurnal IImu Sosial, Politik Dan Humaniora E-ISSN : 2598-6236

http://jurnal.um-tapsel.ac.id/index.php/muqoddimah
Pengaruh Australia Terhadap Kebijakan Domestik Indonesia Dalam Menanggulangi Aksi Terorisme Bom Bali Satu

(Yeni Oktarina, Regina Putri Mulyawati, Sheila Hannah Damayanti, Nabila Farah Khanuris)

kejahatan transnasional atau kejahatan lintas negara memang untuk menakut-nakuti semua kalangan, karena meskipun sasaran para teroris ini hanya satu kelompok tapi banyak warga sipil atau masyarakat yang tidak bersalah juga terkena imbasnya.

Setelah Bom Bali I terjadi, Indonesia dan Australia pun menjalin kerja sama internasional. Ada beberapa bentuk kerja sama internasional dalam kasus terorisme antara Indonesia dan Australia, tergantung dari siapa presiden yang menjabat di Indonesia. Pada saat kasus bom ini terjadi, Presiden Megawati Soekarno putri sedang menjabat. Kerja sama internasional yang mereka buat adalah dengan ditandatanganinya Memorandum of Understanding between the Government of the Republic of Indonesia and the Government of Australia on Combating International Terrorism. Pada era Presiden Susilo Bambang Yudhoyono kerja sama ini diwujudkan dengan ditandatanganinya Nota Kesepahaman dan juga diselenggarakannya program Post Blast Incident Management. Pada bulan berikutnya, diadakan pelatihan identifikasi korban (DVI) dan pelatihan investigasi TKP yang dipandu oleh AFP Australia. Terakhir, pada era Presiden Joko Widodo, kerja sama keduanya diwujudkan dengan dibuatnya perjanjian yang melibatkan AFP dan Polri, penandatanganan Nota Kesepahaman, pelaksanaan forum dan workshop, juga kerja sama dalam rangka pencegahan pembiayaan terorisme. (Nala Nourma Nastiti, 2017)

Penelitian ketiga adalah jurnal dari Cesarani Rilistya yang berjudul Implementasi Kerjasama Indonesia dengan AS Dalam Penanganan Aksi Terorisme di Indonesia.("IMPLEMENTASI KERJASAMA INDONESIA DENGAN AS DALAM PENANGANAN AKSI TERORISME DI INDONESIA," 2015) Penelitian ini merupakan penelitian mengenai adanya kerjasama antar Indonesia dan Amerika Serikat melalui terjadinya bom Bali pertama pada tahun 2002 dimana dalam kasus tersebut pengeboman tidak hanya terjadi di beberapa tempat klub namun juga terjadi di kantor konsulat Amerika Serikat oleh karena itu peneliti Cesarani mengkaji mengenai adanya bentuk kerja sama antar Indonesia dengan pihak AS.

Selain itu Cesarani juga menjabarkan melalui tragedy bom bali pertama tersebut menjadi titik balik terhadap Indonesia dalam kasus terorisme. Diharapkan dengan adanya kerja sama dengan AS tersebut yang mana pada tahun sebelumnya telah terjadi kasus terorisme 9/11 sehingga dapat membentuk kestabilitasan keamanan antar sesama 248 negara. Terutama dalam kekhawatirannya terhadap kelompok-kelompok islam radikal lainnya yang mana di Indonesia mayoritas merupakan salah satu pemeluk agama islam terbesar.

Penelitian keempat adalah jurnal dari Ari Ulandari, Yoedhi Swastanto dan Effendi Sihole yang berjudul Implementasi Kerjasama Kontra-Terorisme Indonesia Australia. (Ari Ulandari, 2019) Penelitian ini membahas tentang latar belakang kerja sama antara Indonesia Australia dalam menangapi kasus terorisme dengan membuat kebijakan Kontra-Terorisme. Dimana sebelumnya Australia dan Indonesia sangat bertolak belakang dalam respon terhadap isu terorisme. Namun kedua negara tersebut akhirnya sepakat untuk bekerja sama karena adanya kepentingan yang sama dalam menghadapi kasus terorisme, khususnya dalam penanganan Bom Bali I ini. Yang akhirnya karena adanya penanganan Bom Bali, Autralia dapat merubah arah kebijakan Kontra-Terorisme Indonesia dari yang sebelumnya pasif menjadi aktif kembali dan lebih agresif.

Dari latar belakang yang sudah dijelaskan, maka penulis akan memfokuskan permasalahan yang akan diteliti sebagai berikut; Bagaimana pengaruh Australia terhadap kebijakan domestik Indonesia dalam menanggulangi aksi terorisme bom Bali satu?

\section{METODE}

Pada penelitian ini melakukan pengumpulan data dengan menggunakan metode kualitatif. Metode kualitatif terhadap penelitian ini yaitu untuk dapat mengkaji pengaruh Australia terhadap kebijakan domestik Indonesia dalam menanggulangi aksi terorisme bom Bali satu secara rinci dan berdasar pada sumber referensi yang peneliti dapatkan. 
JURNAL ILMIAH MUQODDIMAH: Jurnal IImu Sosial, Politik Dan Humaniora E-ISSN : 2598-6236

http://jurnal.um-tapsel.ac.id/index.php/muqoddimah
Pengaruh Australia Terhadap Kebijakan Domestik Indonesia Dalam Menanggulangi Aksi Terorisme Bom Bali Satu

(Yeni Oktarina, Regina Putri Mulyawati, Sheila Hannah Damayanti, Nabila Farah Khanuris)

Dalam penelitian ini untuk teknik analisa data yang digunakan yaitu bersifat sekunder yaitu dengan data-data yang diperoleh dari buku, jurnal, berita dan internet serta data yang penulis gunakan berupa telaah pustaka (library research) dan studi dokumen, yang mana dalam hal ini dengan cara mengumpulkan literatur penelitian berkaitan dengan pokok permasalahan. Penelitian ini juga diharapkan dengan penulisan yang dibuat secara deskriptif dapat memudahkan pembaca agar dapat mengetahui permasalahan yang telah dikaji.

\section{HASIL DAN PEMBAHASAN}

\section{Kasus Bom Bali Satu dan Kebijakan Publik mengenai Terorisme di Indonesia}

Setelah terjadinya insiden $9 / 11$, istilah terorisme mulai banyak dibicarakan. Bahkan dalam kerjasama internasional pun. Dalam adanya kejadian terorisme ini, Asia Tenggara disebut-sebut menjadi 'penghubung' bagi berbagai aktivitas dari terrorisme global. Berkembangnya kelompokkelompok terorisme ini diduga karena lemahnya pemerintah negara Indonesia dalam merespon isu terorisme serta masyarakat Indonesia yang rentan sehingga perbatasannya mudah dilintasi berbagai macam orang tanpa tahu jika terorisme masuk dan lebih berulah lagi. Hingga adanya kejadian Bom Bali yang diduga sebagai respon para pelaku terhadap pimpinan Al-Qaeda, Usama Bin Laden dan Aymanal-Zawahiri yang rekaman suaranya disebarkan oleh Al-Jazeera pada tanggal 6 Oktober 2002 yang mana mengajak kembali menyerang kepentingan barat. Serangan pertama kalinya dilakukan pelaku bom bunuh diri di Indonesia untuk menunjukkan peningkatan aktivitas terorisme yang ada di Asia Tenggara. (Ari Ulandari, 2019) Dengan banyaknya kejadian-kejadian akibat dari terorisme hingga adanya peristiwa Bom Bali ini mengakibatkan Indonesia menjadi sorotan dunia Internasional. Negara-negara barat menaruh perhatian lebih kepada Indonesia bukan hanya karena adanya aktivitas-aktivitas terorisme yang terjadi di Indonesia melainkan juga karena Indonesia merupakan sebuah negara dengan mayoritas penduduk muslim terbesar di dunia yang mana diharapkan dapat tampil sebagai "The moderate face" sehingga dapat memperlihatkan wajah dari Islam yang lebih toleran dan damai. (Ari Ulandari, 2019)

Adanya kejadian Bom Bali I ini bukan semata-mata karena pemerintah Indonesia menutup mata rapat-rapat tentang aksi terorisme. Sebelumnya, pada masa Orde Lama kebijakan dan strategi penanggulangan terorisme tersebut dilaksanakan melalui pendekatan keamanan dengan operasi militer yang berbasis UU Subversif (Penetapan Presiden RI No.11/1963). Begitu pun pada masa Orde Baru, namun kali ini lebih menekankan pada operasi intelijen sebagai ujung tombak, dan Penetapan Presiden RI No. 11/1963 dikuatkan menjadi UU No.11/PNPS/1963 dan menjadi suatu dasar hukum pemberantasan terorisme (Widyawati, 2019). Kemudian, pada era reformasi UU No.11/PNPS/1963 sudah tidak diberlakukan lagi karena dianggap tidak sesuai dengan sistem demokrasi. Dalam era ini juga yang mana pemerintah mengeluarkan Perpu No. 1 Tahun 2002 yang disahkan menjadi UU No. 15 Tahun 2003 tentang Pemberantasan Tindak Pidana Terorisme. Kemudian undang-undang tersebut direvisi dengan UU No. 5 Tahun 2018 tentang Perubahan Atas UU No. 15 Tahun 2003 tentang Pemberantasan Tindak Pidana Terorisme. Lebih lanjut, pada tahun 2010 pemerintah menerbitkan Perpres No. 46 Tahun 2010 tentang pembentukan Badan Nasional Penanggulangan Terorisme (BNPT) yang mana pada tahun 2012 diubah dengan Perpres No. 12 Tahun 2012. Pembentukan BNPT ini merupakan kebijakan negara yang bertujuan untuk menanggulangi terorisme di Indonesia yang menekankan upaya integrative dan komprehensif, juga menomorsatukan pendekatan persuasif dengan berbagai macam program, yaitu: ideologi, ekonomi, sosial, dan ketidakadilan. BNPT juga merupakan sebuah pengembangan dari Desk Koordinasi Pemberantasan Terorisme (DKPT) yang mana dibuat pada tahun 2002. (Hanafi, 2019)

Dalam membuat kebijakan terorisme dalam negeri ini pada dasarnya ketika era orde lama kebijakan serta strategi dalam menanggulangi terorisme dilakukan dengan menggunakan pendekatan keamanan melalui operasi militer berbasis UU Subversif. Pada era Orde Baru, 
JURNAL ILMIAH MUQODDIMAH: Jurnal IImu Sosial, Politik Dan Humaniora E-ISSN : 2598-6236

http://jurnal.um-tapsel.ac.id/index.php/muqoddimah
Pengaruh Australia Terhadap Kebijakan Domestik Indonesia Dalam Menanggulangi Aksi Terorisme Bom Bali Satu

(Yeni Oktarina, Regina Putri Mulyawati, Sheila Hannah Damayanti, Nabila Farah Khanuris)

dalam penanggulannya cukup hampir sama terhadap era lama yang mana mendasarkan pada UU subversif serta lebih memfokuskan dalam operasi intelijen. Saat masa reformasi, demokratis, kebebasan, yang mana terdapat pada perspektif HAM terhadap beberapa sector bahwasaanya dapat memberikan dampak kebijakan dan strategi melalui adanya penanggulangan terorisme yang utamanya mementingkan aspek penegak hukum dalam lahirnya UU Nomor 15 tahun 2003 tentang adanya pemberantasan terhadap Tindak Pidana Terorisme yang mana dalam perubahan kebijakan ini dilandasi melalui dinamika global atau adanya pasca konflik terjadinya bom Bali pertama pada tahun 2002.

Selain kebijakan-kebijakan pemerintah yang telah disebutkan sebelumnya, terdapat pula upaya pemerintah yang bersifat memerangi, membasmi, dan juga eliminasi terhadap pelaku terorisme yang mana bersifat represif dan diimbangi dengan upaya pencegahan seperti pengamanan wilayah territorial, kerjasama antar negara, menyempurnakan sistem deteksi, memperkuat prosedur pengawasan, perlindungan diplomat dan konsul dalam misi internasional, dan lain-lain. Meskipun demikian, kebijakan-kebijakan dan upaya tersebut ditengarai tidak cukup memberantas pelaku terorisme dan kemungkinan kasus-kasus yang akan datang. Kebijakan dan upaya tersebut juga dinilai belum efektif dalam menggapai akar dan inti dari jaringan terorisme yang ada.

\section{Upaya Indonesia dalam Membentuk Jejaring terhadap Kebijakan tentang Terorisme.}

Dalam mengatasi isu terorisme ini, Indonesia memiliki peran yang sangat aktif termasuk dibawah PBB. Menjadi pembelajaran tersendiri bagi Indonesia setelah adanya peristiwa Bom Bali pertama ini menjadikan Indonesia aktif sebagai negara yang mengampanyekan mengenai terrorisme. Indonesia sendiri memiliki peran penting dalam penanggulangan terorisme internasional dan telah diakui oleh PBB dengan terpilihnya kembali Indonesia sebagai anggota Dewan Penasihat UN Counter-Terorrorism Center peda periode 2015-2018 (Kemlu.go.id, 2019).

Terjadinya konflik dari terorisme bom bali satu ini terhadap kebijakan dalam negeri Indonesia membuat pemerintah memutuskan untuk dapat melakukan kerja sama dengan beberapa pihak negara. Dalam hal ini sebelum membahas adanya jaringan yang dibentuk Indonesia dengan Australia yang membawa keberhasilan besar dalam penanganan terorisme Bom Bali, di sisi lain Indonesia juga sempat bekerja sama dengan Amerika serikat. Dengan pertimbangan jika Indonesia sebagai negara yang demokrasi yang juga mayoritas pemeluk Islam terbesar. Adanya kesamaan dalam permasalahan terorisme antara kedua negara ini, dipandang bahwa masalah terorisme ini adalah masalah lintas negara, sehingga kedua negara bersepakat untuk bekerjasama dalam kontra-terorisme. Implementasi dalam kerjasama terhadap penanggulangan terorisme dapat diterapkan dalam job desk pada program-program yang telah dibentuk, yaitu seperti Anti Terrorism Assistance (ATA) yang mana Program tersebut melalui Bureau of Diplomatic Security dari AS sebagai Densus 88 Anti Teror Polri serta Regional Defense Combating Terrorism Fellowship Program (CTFP) melalui Department of Defense (DoD) untuk TNI. Anti-Terrorism Assistance (ATA) Program dalam Densus 88 berperan besar dalam mejalankan kontra-terorisme di Indonesia. Kemampuan yang dimiliki Densus 88 ini karena adanya potensi polisi-polisi Indonesia yang secara khusus dan diam-daim dilatih oleh FBI, dimana Amerika Serikat yang mendanai pelatihan-pelatihan untuk pasukan khusus.

Dalam hal ini adapun kerjasama antara Indonesia dan Australia dalam menangani kasus terorisme ini yang dilakukan antara kedua negara sebagai puncak dari kerjasama dengan Indonesia. Dimana yang sebelumnya Australia dan Indonesia sangat bertolak belakang dalam respon terhadap isu terorisme. Namun kedua negara tersebut akhirnya sepakat untuk bekerjasama karena adanya kepentingan yang sama dalam menghadapi kasus terorisme, khususnya dalam penanganan Bom Bali I ini. Australia berperan sebagai pendukung atau Back up (personil AFP dari Australia) POLRI dalam pengungkapan kasus Bom Bali. 
JURNAL ILMIAH MUQODDIMAH: Jurnal IImu Sosial, Politik Dan Humaniora E-ISSN : 2598-6236

http://jurnal.um-tapsel.ac.id/index.php/muqoddimah
Pengaruh Australia Terhadap Kebijakan Domestik Indonesia Dalam Menanggulangi Aksi Terorisme Bom Bali Satu

(Yeni Oktarina, Regina Putri Mulyawati, Sheila Hannah Damayanti, Nabila Farah Khanuris)

Dalam kerjasama yang dibuat ini Indonesia juga berkepentingan untuk memulihkan kondusifitas di Bali karena berkaitan dengan devisa serta kesejahteraan rakyat. Terorisme yang termasuk kejahatan lintas batas yang mana tidak akan bisa jika suatu negara harus bergerak menangani masalah ini seorang diri saja, dan karena pelaku memiliki kemampuan teknologi yang bagus dan kompleks jalan satunya-satunya agar bisa menuntaskan masalah dan mengalahkan terorisme tentu harus dengan jalan kerjasama. Kerja sama Resiprokal antara Indonesia Australia. Dimana Australia memang memiliki nilai tinggi dalam bidang finansial dan teknologi, stabil, demokratik, sistem hukum yang kuat, penghargaan terhadap HAM yang tinggi, Australia juga memiliki kredibilitas yang solid serta struktur manajemen yang kuat. Sedangkan Indonesia sendiri lebih memiliki nilai lebih disisi yang lain dari Australia, yakni seperti Anggota G20, leader di ASEAN, negara yang demokratis dan bersinergi dengan yang mayotas muslim. Jadi mampu saling melengkapi dan cocok untuk strategi dalam pemberantasan terorisme ini. Dimana Indonesia juga memiliki skills, ideologi dan sistem pertahanan yang kuat jika dibandingkan dengan negara lain yang ada dalam kawasan Asia tenggara ini.("IMPLEMENTASI KERJASAMA INDONESIA DENGAN AS DALAM PENANGANAN AKSI TERORISME DI INDONESIA," 2015)

\section{Hasil dari pengaruh kerjasama dengan Australia dalam menjaga keamanan domestic dan Internasional di Indonesia.}

Pihak pemetintah Autralia menyediakan informasi dan teknologi yang belum dimiliki oleh Indonesia dan dibutuhkan dalam operasi pengungkapan kasus. Dimana rasa percaya diri dan rasa saling menghargai dan menghormati dari kedua kubu negara antara personil AFP dan POLRI ini sangat tinggi antar satu sama lain sehingga tuntaslah permasalahan ini dengan baik. Tuntasnya pengungkapan Bom Bali I ini menguntungkan bagi Autralia, dimana bisa menyelesaikan kasus yang membuat hampir semua warganya menjadi sebagai korban. Serta Autralia menjadi memiliki nilai lebih tinggi dari segi finansial dan teknologi yang kuat.("IMPLEMENTASI KERJASAMA INDONESIA DENGAN AS DALAM PENANGANAN AKSI TERORISME DI INDONESIA," 2015) Membahas tentang apa yang meletar belakangi kerja sama antar Indonesia dan Autralia, semua itu demi satu tujuan yakni kepentingan nasional, bagi Indonesia sendiri maupun Australia.

Selain itu juga kerjasama Indonesia dan Australia dalam membuat kebijakan domestik terkait dengan terorisme ini tentunya ingin memberantas teroris yang mama mereka berhasil membentuk suatu keamanan, dimana Australia membantu polri dalam pemberantasan terorisme dengan memberi bantuan Detasemen khusus 88 Anti-Teror atau densus 88 yang mana arti 88 sendiri adalah jumlah dari warga Australia yang meninggal saat Bom Bali. Adapun dalam aspek yang lain yakni dalam kerjasama ekonomi dengam memberi bantuan uang diamana bantuan tersebut digunakan untuk melacak aliran dana teroris, meningkatkan keamanan pariwisata, dan memperkuat kapasitas kepolisian indonesia dalam menghadapi terorisme dan kejahatan transnasional yang lainnya.

Implementasi kerjasama yang dibangun antara kedua negara ini dalam Bom Bali lebih disoroti di dua hal yang pertama dalam penanganan korban dan penanganan kasus terornya. Korban yang meninggal maupun luka-luka itu kebanyakan dari orang asing oleh sebab itu kerjasama Internasional dilakukan. Dalam proses penanganan korban memang banyak terjadi masalah, namun dengan cepat Indonesia resmi memberitakan tentang 202 korban meninggal, 317 luka-luka. (Abdulsalam, 2018) Dan dengan demikian semua orang pas dengan jumlah awal yakni 519 orang. Hal lainnya mengenai pelaku teror yang mana Kasus Bom Bali ini pelakukanya adalah dari sekelompok orang yang berafiliasi dengan organisasi Jamaah Islamiyah (JI) yang mana bukan hanya di Indoneisa, namun dalam kawasan ASEAN anggotanya juga terdapat dari Malaysia, Singapura dan juga Filipina. Kelompok JI ini diduga ada 1500 anggota di Indonesia dan juga sudah berkembang di Autralia selama bertahun-tahun sebelum 2002. Bom Bali ini 
JURNAL ILMIAH MUQODDIMAH: Jurnal IImu Sosial, Politik Dan Humaniora E-ISSN : 2598-6236

http://jurnal.um-tapsel.ac.id/index.php/muqoddimah
Pengaruh Australia Terhadap Kebijakan Domestik Indonesia Dalam Menanggulangi Aksi Terorisme Bom Bali Satu

(Yeni Oktarina, Regina Putri Mulyawati, Sheila Hannah Damayanti, Nabila Farah Khanuris)

terjadi dengan adanya tiga ledakan yang menurut Grahan Ashton ada kaitannya dengan pencurian $400 \mathrm{~kg}$ klorat di Jawa pada bulan september 2002. (News, 2020)

Dan juga jika dilihat dari jumlah para pemimpin teroris yang berhasil ditangkap dan serapa banyak teroris yang dapat dibunuh maka kerjasama Indonesia-Australia tersebut bisa disebut sangat efektif dan berhasil. Terbukti dalam hal ini dengan tertangkap dan diadilinya terhadap seluruh pelaku inti Bom Bali, meskipun ternyata 'pelaku' paling berbahaya, ialah Dr. Azahari, baru bisa diatasi pada tahun 2005.("IMPLEMENTASI KERJASAMA INDONESIA DENGAN AS DALAM PENANGANAN AKSI TERORISME DI INDONESIA," 2015) Dalam adanya kerjasama yang dibentuk ini menguntungkan bagi sesama pihak dalam terjadinya konflik terror bom bali pertama ini dan bagi Indonesia sendiri kerjasama ini demi terciptanya keamanan nasional.

Alasan dari Indonesia dan Australia menjalin kerjasama dalam kasus terorisme Pasca Bom Bali ini adalah untuk kepentingan nasional masing-masing dari kedua negara tersebut. Dari sisi Australia sendiri adalah karena ingin membantu merampungkan masalah yang sudah membunuh banyak warganya dan Indonesia yang berkepentingan untuk menyelamatkan dan memperbaiki reputasi kemanan negara di lingkup domestic dan internasional.

\section{SIMPULAN DAN SARAN}

Berdasarkan dari penjelasan diatas, dapat disimpulkan bahwa aksi terrorisme bukanlah sebuah kejahatan baru. Akan tetapi menjadi fokus dunia kembali setelah adanya aksi terorismme di gedung WTC New York dan sebagian gedung Pentagon DC pada tanggal 11 September 2001. Dengan adanya kasus ini, kembali membuka mata dunia, bahwa perlu diadakannya sebuah kebijakan yang dapat mengatur mengenaiaksi terorisme ini dengan serius.

Pada tahun 2002, Indonesia dikejutkan dengan aksi pengeboman di Bali yang menewaskan warga local dan sebagian warga negara asing (WNA). Dengan adanya kejadian terorisme, Indonesia langsung mengambil langkah untuk mengatasi permasalahan tersebut. Dengan tujuan agar dapat mengatasi terorisme, serta dapat mengembalikan citra Indonesia di mata Internasional.

Indonesia membuat kebijakan-kebijakan domestic yang di atur dalam Undang-Undang, serta menjalin kerjasama dengan negara lain, seperti Amerika dan juga Australia. Namun, kerjasama dengan Australia dilakukan lebih intens, mengingat dalam kasus pengeboman bali, WNA Australia merupakan korban WNA terbanyak. Sehingga tidak diragukan lagi untuk menjalin kerjasama diantara kedua negara tersebut.

Dengan adanya kerjasama tersebut telah menghasilkan kebijakan mengenai kontraterorisme, dan pembentuan Densus 88 yang digunakan agar dapat menangkap para sindikat terorisme ini. Seperti yang telah dijelaskan sebelmnya, alasan dari Indonesia dan Australia menjalin kerjasama dalam kasus terorisme Pasca Bom Bali ini adalah untuk kepentingan nasional masing-masng dari kedua negara tersebut.

Dalam menyelesaikan kasus ini, Indonesia melakukan berbagai cara agar dapat memusnahkan terorisme, dan agar tidak terjadi lagi aksi yang serupa. Indonesia juga perlu membuat kebijakan-kebijakan yang kuat, serta menjalin kerjasama dengan banyak negara, mengingat Indonesia yang mayoritas penduduknya adalah Muslim, dan terorisme selalu dikaitkan dengan Muslim. Sehingga hal tersebut juga menjadi pertimbangan kepada Indonesia untuk segera memperbaiki citra Indonesia di mata dunia.

\section{DAFTAR PUSTAKA}

Firmansyah, H. (2011). Upaya Penanggulangan Tindak Pidana Terorisme di Indonesia. Mimbar Hukum-Fakultas Hukum Universitas Gadjah Mada, 23(2), 376-393. Diakses dari https://journal.ugm.ac.id/jmh/article/view/16193 
JURNAL ILMIAH MUQODDIMAH: Jurnal IImu Sosial, Politik Dan Humaniora E-ISSN : 2598-6236

http://jurnal.um-tapsel.ac.id/index.php/muqoddimah
Pengaruh Australia Terhadap Kebijakan Domestik Indonesia Dalam Menanggulangi Aksi Terorisme Bom Bali Satu

(Yeni Oktarina, Regina Putri Mulyawati, Sheila Hannah Damayanti, Nabila Farah Khanuris)

Hanafi, B. P. (2019). STRATEGI MENGHADAPI PAHAM RADIKALISME TERORISME. AI Imam: Jurnal Manajemen Dakwah, 117-135. Diakses dari https://ejournal.uinib.ac.id/jurnal/index.php/alimam/article/view/1059

Jemadu, A. 2008. Politik Global dalam Teori \& Praktik. Yogyakarta: Graha IImu

Kurniawati, D. E. (2013). Pendekatan Intermestik Dalam Proses Perubahan Kebijakan: Sebuah Review Metodologis. Jurnal Studi Hubungan Internasional, 2(2), 154-167. Diakses dari http://ejournal.umm.ac.id/index.php/jshi/article/view/1519/1623

Mukhtar, S. (2016). Strategi Pemerintah Indonesia Menghadapi Terorisme Dalam Era Demokratisasi. Reformasi: Jurnal IImiah IImu Sosial dan IImu Politik, 6(2). Diakses dari https://45.32.120.76/index.php/reformasi/article/view/691.

Nastiti, Nala Nourma Y. O. (2017). TANTANGAN IMPLEMENTASI KERJASAMA ANTI TERORISME ANTARA INDONESIA DAN AUSTRALIA TAHUN 2007-2016. Dinamika Global, 68-112. Diakses dari http://fisip.unjani.ac.id/wp content/uploads/2018/03/TantanganImplementasi-Kerjasama-Anti-Terorisme-Antara-Indonesia-dan-Australia-Tahun-2007-2016Nala-Nourma-Nastiti-Yuswari-O-Djemat-Indah-Dwiprigitaningtias.pdf

Pratiwi, D. A. (2016). KEBIJAKAN LUAR NEGERI INDONESIA DALAM TERORISME INTERNASIONAL. JURNAL DIMENSI, 4(1). Diakses dari https://www.journal.unrika.ac.id/inde x.php/jurnaldms/article/download/28/26

Rilistya, Cesarani. IMPLEMENTASI KERJASAMA INDONESIA DENGAN AS DALAM PENANGANAN AKSI TERORISME DI INDONESIA. Journal of International Relations, Volume 2, Nomor 1, Tahun 2016, hal. 166-173. Diakses dari http://ejournals1.undip.ac.id/index.php/jihi

Simanjuntak, Shara Yosevina. 2016. Analisis Kerja Sama Bilateral Indonesia dengan Australia dalam Penanggulangan Terorisme sebagai Kejahatan Transnasional Teroganisir (20022015). Journal of International Relations. 2(3). Hal. 117-127. Diakses dari https://ejournal3.undip.ac.id/index.php/jihi/article/viewFile/12262/11912

Ulandaril, Ari. Dkk. 2019. ImplementasiKerja Sama Kontra-Terorisme Indonesia-Australia (StudiKasus Bom Bali I Tahun 2002). Jurnal Diplomasi Pertahanan 5(3). Hal 29-58. Diakses dari http://139.255.245.7/index.php/DP/article/view/441

Widyawati, Lidya Suryani. 2019. KEBIJAKAN KRIMINAL DALAM PEMBERANTASAN TERORISME. Info Singkat. Hal 2-3. Diakses dari file://C:/Users/ASUS\%20A407UB/Documents/SEM\%204/intermestik/Info\%20Singkat-XI22-II-P3DI-November-2019-186.pdf

Abdulsalam, H. (2018).Bom Bali 2002: Kebiadaban Teroris dan Duka Para Korban. Tirto.id. 12 Oktober 2018. Diakses dari https://tirto.id/bom-bali-2002-kebiadaban-teroris-dan-dukapara-korban-c5GL

Adyatama, E. (2020). Gairah TNI Ikut Tangani Terorisme Menguat Kembali. Tempo.co. 11 Mei 2020. Diakses dari https://fokus.tempo.co/read/1341111/gairah-tni-ikut-tangani-terorismemenguat-kembali

BBC News Indonesia. (2017). Pasang Surut Hubungan Australia dan Indonesia: Tegang Namun Pragmatis. BBC News. 6 Januari 2017. Diakses dari https://www.bbc.com/indonesia/dunia-38527300

BBC News Indonesia. (2010). Profil Jamaah Islamiyah. BBC News. 20 September 2010. Diakses dari https://www.bbc.com/indonesia/berita indonesia/2010/09/100922 jamaahislamiyah

CNN Indonesia. (2020). Militer Tak Tunduk Peradilan Umum, Perpres Terorisme Diprotes. CNN News. 10 Mei 2020. Diakses dari https://m.cnnindonesia.com/nasional/2020051005300920-501696/militer-tak-tunduk-peradilan-umum-perpres-terorisme-diprotes

Indonesia dan Upaya Penanggulangan Terorisme. Kementerian Luar Negeri Indonesia. Kemlu.go.id. 7 April 2017. Diakses dari https://kemlu.go.id/portal///read/95/halaman_list_lainnya/indonesia-danupaya-penanggulangan-terorisme\# 
Nurdin, E. (2020). Anak Korban Bom Bali 1 ke pelaku: 'Saat umur 10 tahun, saya lihat jenazah ayah hangus, bayangkan kalau Bapak jadi saya'. BBC News. 17 Februari 2020. Diakses dari https://www.bbc.com/indonesia/indonesia-50408538

Prastiwi, D. (2018). Fakta-Fakta Usai Meledaknya Bom Bali 1. Liputan 6. 12 Oktober 2018. Diakses dari https://m.liputan6.com/news/read/3665634/5-fakta-usai-meledaknya-bombali-i

Wijayaka, B. (2018).Penanggulangan Terorisme, Indonesia dan AS Kerja Sama. BERITA SATU. 14 September 2018. Diakses dari https://amp.beritasatu.com/nasional/510520/nasional/510520penanggulangan-terorisme-indonesia-dan-as-kerja-sama 